\title{
Leukoencephalopathy with brainstem and spinal cord involvement and lactate elevation: The presentation of a rare case
}

\section{Beyin sapı ve omurilik tutulumu ve laktat yükselmesi olan Iökoensefalopati: Nadir bir olgu sunumu}

\author{
Mehmet Haydar Atalar ${ }^{1}$, Abdurrahman Gölbași², Büllent Yildlı²
}

' Cumhuriyet University School of Medicine, Department of Radiology, Division of Pediatric Radiology, Sivas, Turkey

${ }^{2}$ Cumhuriyet University School of Medicine, Department of Radiology, Sivas, Turkey

Corresponding author: Mehmet Haydar Atalar, Cumhuriyet University School of Medicine, Department of Radiology, Division of Pediatric Radiology, Sivas Turkey

E-mail: mhatalar@gmail.com

Received/Accepted: July 12,2017 / January 06, 2018

Conflict of interest: There is not a conflict of interest.

\section{SUMMARY}

Characterized by brain stem and spinal cord involvement and elevated lactate level, leukoencephalopathy (LBSL) is a white matter disease that has been newly described on the basis of magnetic resonance imaging (MRI) signs. The clinical signs and symptoms indicate progressive pyramidal, cerebellar, and dorsal column dysfunction. Its laboratory findings are generally non-revealing. There are some typical MRI and magnetic resonance spectroscopy (MRS) signs. We present a 11-year-old boy patient with cerebellar, pyramidal and dorsal column dysfunctions and specific MRI and characteristic MRS findings. MRI and MRS findings were consistent with LBSL. LBSL is a rare leukoencephalopathy. The imaging features are very specific, and radiology has a key role to play in directing the diagnosis and management. Keywords: Magnetic resonance imaging, leukoencephalopathy, spectroscopy, spinal cord

ÖZET

Beyin sapı ve omurilik tutulumu ve yüksek laktat seviyesi ile karakterize olan lökoensefalopati (LBSL), manyetik rezonans görüntüleme (MRI) işaretleri temelinde yeni tanımlanan beyaz cevher hastalığıdır. Klinik bulgular ve semptomlar ilerleyici piramidal, serebellar ve dorsal kolon ișlev bozukluğunu gösterir. Laboratuvar bulguları genellikle ortaya çıkarılmamaktadır. Bazı tipik MR ve manyetik rezonans spektroskopisi (MRS) bulguları vardır. Serebellar, piramidal ve dorsal kolon fonksiyon bozukluğu olan, spesifik MR ve karakteristik MRS bulguları olan 11 yaşında bir erkek hasta sunuyoruz. MR ve MRS bulguları LBSL ile uyumlu idi. LBSL, nadir bir lökoensefalopatidir. Görüntüleme özellikleri çok özeldir ve radyolojinin tanı ve tedaviyi yönlendirmede önemli bir rolü vardır.

Anahtar sözcükler: Manyetik rezonans görüntüleme, lökoensefalopati, spektroskopi, spinal kord

\section{INTRODUCTION}

Characterized by brain stem and spinal cord involvement and elevated lactate level, leukoencephalopathy (LBSL) is a white matter disease that has newly been described on the basis of magnetic resonance imaging (MRI) signs. The disease results from a mutation in the DARS2 gene encoding for mitochodrial aspartyl tRNA synthase and transmitted in autosomal an recessive pattern ${ }^{1}$. The clinical signs include progressive pyramidal cerebellar and dorsal column dysfunction. Herein, we present a 11year-old boy who was diagnosed with LBSL on the basis of MRI signs after having presented with amnesia, gait imbalance, and weakness, the latetr being more prominent in his lower extremities. 


\section{CASE REPORT}

A 11-year-old boy presented with amnesia, gait imbalance, and weakness, notably in lower extremities. His laboratory examinations were within normal limits. MRI, diffusion-weighted imaging (DWI), and magnetic resonance spectroscopy (MRS) were performed with a $1.5 \mathrm{~T}$ MRI device. Brain MRI examination with T2 weighted images revealed symmetrical, diffuse and homogenous hyperintense lesions in bilateral periventricular and deep white matter, which did not extend to U fibers (Figures. 1A, B). There was involvement of lateral corticospinal tracts, pyramidal tracts, inferior cerebellar pedicles, and along the spinal cord (Figure. 2A, B). DWI showed marked limitiation of diffusion, partciularly in lesions located in the periventricular and deep white matter.

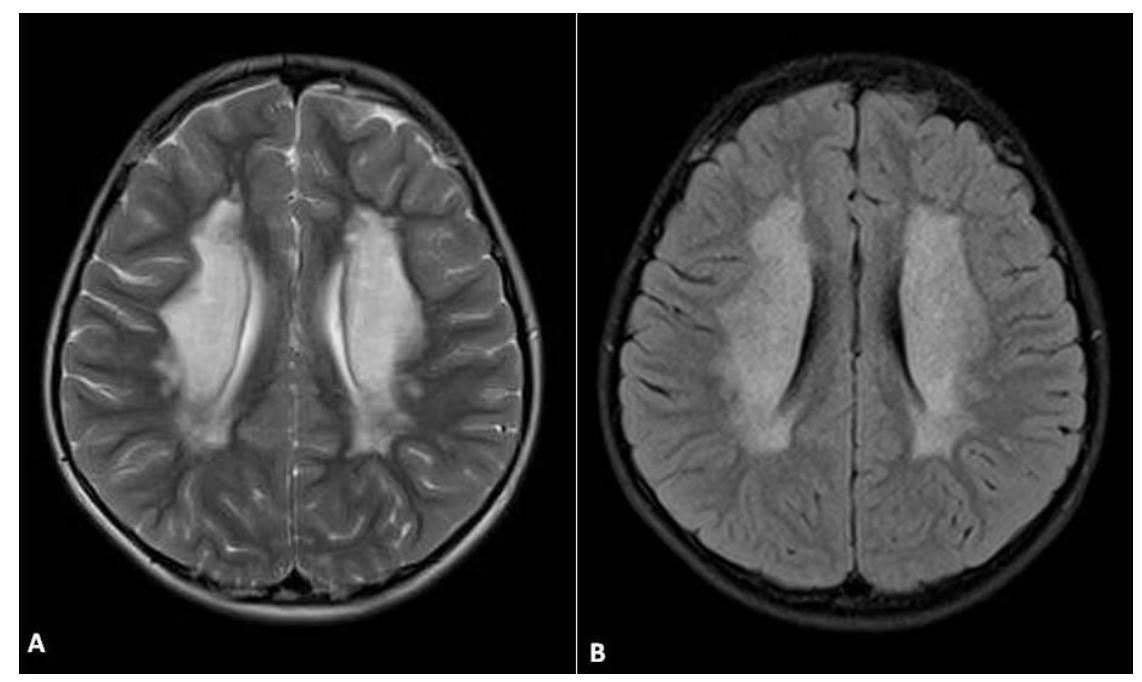

Figure 1. Axial (A) T2 weighted and (B) FLAIR MR images show diffuse hyperintense signal changes in bilateral periventricular and deep white matter.

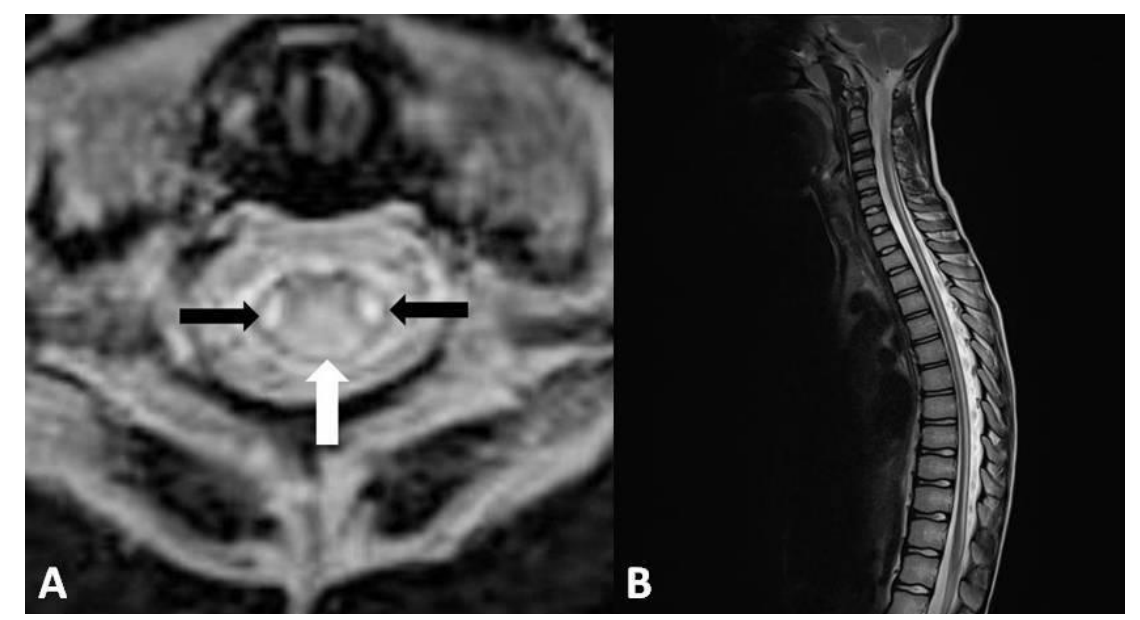

Figure 2. (A) Axial T2 weighted image of the spinal cord at the level of C1-2 shows increased signal involving the dorsal column (white arrow) and lateral corticospinal tracts (black arrows), and (B) sagittal T2 weighted MR image shows abnormal signal intensity along the spinal cord. 


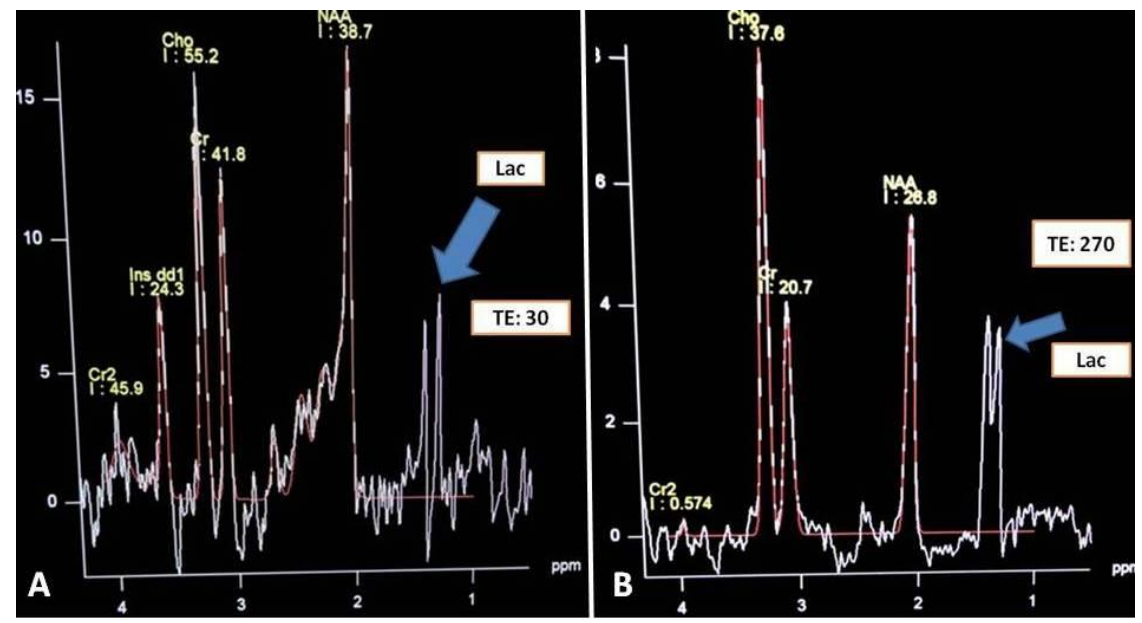

Figure 3. (A) TE: $30 \mathrm{msec}$ and (B) TE: $270 \mathrm{msec}$ magnetic resonance spectroscopic examinations of periventricular white matter show lactate peaks at $1.3 \mathrm{ppm}$ (blue arrows). (TE: Time to Echo).

A MRS examination of the periventricular white matter showed a marked reduction of $\mathrm{N}$-acetyl aspartate (NAA), a marked increased in myoinositol, and a mild increase in choline. There was an elevated lactate peak in spectra at $1.3 \mathrm{ppm}$ (Figures. 3A, B).

LBSL was diagnosed in the light of MRI findings. Genetic study for mutational gene localization was not available in our hospital. A genetic study at another center was recommended to the parent of the patient. The patient was followed up for possible progression of clinical findings.

\section{DISCUSSION}

LBSL was first described in 2003 by Knaap et al. in a 8 -case series ${ }^{2}$. Since then, a number of cases have been reported ${ }^{3-5}$. Despite most common in childhood and adolescence, LBSL can also start in the neonatal period or infancy ${ }^{6}$. Early-onset LBSL cases have a severe-fatal course whereas the ones starting in the adolescence or adulthoood are known to have a slower, progressive course. The most common clinical signs of LBSL include cerebellar ataxia and neuronal dysfunction that is more prominent in the lower extremities. Deep tendon reflexes are tyipically spared. Dysarthria may develop over time. Other less common signs and symptoms include epilepsy, imparied consciousness, and learning difficulty. Laboratory tests are usually normal ${ }^{3-6}$.

LBSL is characterized by some typical MRI and MRS signs. To standardize MRI-based diagnosis, 3 major and 7 minor, complementary criteria have been defined on the basis of the revised MR criteria $^{6}$. The diagnosis requires all major criteria and at least one complementary criterion to be met. The major criteria include cerebral involvement of white matter with sparing of subcortical white matter areas, involvement of spinal dorsal column and lateral corticospinal tract, and involvement of medulla oblongata pyramids or medial lemniscus decussation. The minor criteria are the involvement of the splenium of corpus callosum, posterior leg of the internal capsule, superior and inferior cerebellar pedicles, the intraparenchymal part of the trigeminal nerve, mesencephalic trigeminal tract, medulla oblongata anterior spinocerebellar tract, and cerebellar white matter.

Our patient had diffuse confluent T2A and FLAIR hyperintense involvement that did not extend to $\mathrm{U}$ fibers in the bilateral periventricular white matter, with the subcortical areas having been spared. There was also involvement of the dorsal column and lateral corticospinal tracts along the spinal cord, and of the pyramidal tracts at the level of medulla oblongata. Moreover, the posterior legs of the internal capsule, bilateral cerebellar white matter, inferior cerebellar pedicles, parenchymal trigeminal tracts at the level of pons, and anterior corticospinal tracts were also involved. According to the revised MRI criteria for LBSL, our patient met all major criteria and, additionally, all complementary criteria except for the involvement of the posterior leg of corpus callosum.

In LBSL, subcortical U-fibers in particular are not expected to be involved in brain MRI. In 2013, Kassem et al. ${ }^{7}$ retrospectively evaluated and reported the imaging data of 16 patients with LBSL diagnosed by genetic studies. They tabulated the involved and spared regions in the whole study population. Accordingly, the spared 
regions were subcortical U fibers, globus pallidus, mesencephalon, and tranverse pontine fibers. In contrast, in 2011 Galuzzi et al. ${ }^{8}$ reported a case with subcortical $\mathrm{U}$ fiber and globus pallidus involvement.

It can be stated that MRS has a complementary function for the radiological diagnosis of LBSL. MRS findings have been reported in all LBSL cases with a few exceptions. A lactate peak has been observed in the majortiy of these patients. Cases without a lactate peak $^{8,9}$ are adult-onset LBSL cases. Petzold et al. ${ }^{9}$ interpreted this condition that lactate levels may return to normal in the advanced stages of the disease.

Galluzzi et al. ${ }^{8}$ indicated that lactate elevation was non-specific, inconsistent, and thus unreliable for the diagnosis of LBSL. In contrast, the authors stressed that, although not specified in every patient, NAA was low whenever it was sepcified. Thus, they argued that a hypothesis of disease etiopathogenesis should be based on NAA level.

Differential diagnosis on MRI include vitamin B12 deficiency and mitochondrial disorders ${ }^{3-6}$.

In our patient the diffusion weighted examinations showed limitation of diffusion in areas of periventricular deep white matter whereas pathcy areas of increased diffusion were evident in lesions located in brain stem and cerebellum. This suggested that the lesions were in varying stages of development. Clinically, our patient was 11 years old and the disease featured its typical adolescence onset. The reported cases in the literature usually exhibited motor symptoms as the initial complaint. However, our patient's disorder started with amnesia, which can be considered atypical for initial presentation.

LBSL is a newly described, slow-course, albeit progressive, autosomal recessive metabolic disease that is characterized by cerebellar and dorsal column involvement in particular. Its definitive diagnosis requires the demonstration of the characteristic DARS2 gene mutation. MRI and MRS show the typical radiological characteristics of the disease.

\section{REFERENCES}

1. Scheper GC, van der Klok T, van Andel RJ, et al. Mitochondrial aspartyl-tRNA synthetase deficiency causes leukoencephalopathy with brain stem and spinal cord involvement and lactate elevation. Nat Genet 2007; 39: 534- 9.

2. van der Knaap MS, van der Voorn $P$, Barkhof F, et al. A new leukoencephalopathy with brainstem and spinal cord involvement and high lactate. Ann Neurol 2003; 53: 252-8

3. Uluc $\mathrm{K}$, Baskan $\mathrm{O}$, Yildirim $\mathrm{KA}$, et al. Leukoencephalopathy with brain stem and spinal cord involvement and high lactate: a genetically proven case with distinct MRI findings. J Neurol Sci 2008; 273: 118-22.

4. Serkov SV, Pronin IN, Bykova OV, et al. Five patients with a recently described novel leukoencephalopathy with brainstem and spinal cord involvement and elevated lactate. Neuropediatrics 2004; 35: 1-5

5. Linnankivi $T$, Lundbom $N$, Autti $T$, et al. Five new cases of a recently described leukoencephalopathy with high brain lactate. Neurology 2004; 63: 688-92.

6. Steenweg ME, van Berge $L$, van Berkel CG, et al. Early onset LBSL: how severe does it get? Neuropediatrics 2012; 43: 332-8.

7. Kassem H, Wafaie A, Abdelfattah S, Farid. Leukoencephalopathy with brainstem and spinal cord involvement and lactate elevation (LBSL): assessment of the involved white matter tracts by MRI. Eur J Radiol. 2014; 83: 191-6.

8. Galluzzi P, Sacchini M, Bartalini G, Monti L, Cerase A, Lamatea E, et al. LBSL (leukoencephalopathy with brainstem and spinal cord involvement and high lactate) without sparing the u-fibers and globi pallidi: a case report. EJREX. 2011; 79: 73-6.

9. Petzold GC, Bohner G, Klingebiel R, Amberger N, Van der Knaap MS, Zschenderlein R. Adult onset leukoencephalopathy with brain stem and spinal cord involvement and normal lactate. $\mathrm{J}$ Neurol Neurosurg Psychiatry 2006; 77: 889-91. 